\title{
Effect of fumaric acid on diet digestibility and the caecal environment of growing rabbits
}

\author{
Leticia ABECIA, Manuel FONDEVILA*, Joaquim BALCELLS, \\ Alvaro BELENGUER \\ Departamento de Producción Animal y Ciencia de los Alimentos, Universidad de Zaragoza, M. Servet \\ 177, 50013 Zaragoza, Spain
}

(Received 2 December 2004; accepted 22 July 2005)

\begin{abstract}
The inclusion of two doses of fumaric acid (5 and $10 \mathrm{~g} \mathrm{per} \mathrm{kg;} \mathrm{LFA} \mathrm{and} \mathrm{HFA)} \mathrm{in} \mathrm{a} \mathrm{diet}$ for growing rabbits was compared with a subtherapeutic dose of zinc Bacitracin (25 ppm; BAC) and a control (CTL) in terms of apparent nutrient digestibility and caecal environmental parameters. There were no differences between the average fumaric diets and CTL and BAC on total tract apparent digestibility of dry matter (DMD) and organic matter (OMD), but a positive response to the dose of the acidifier was observed $(P=0.05$ and 0.07$)$. However, the digestibility of neutral detergent fibre was not affected by treatments $(P>0.10)$. There was a trend $(P=0.09)$ for a higher microbial N intake as caecotrophes in diets including fumaric acid. This effect increased when the fumaric acid dose was doubled. Although no differences among treatments were detected in total caecal bacterial counts, amylolytic bacterial concentration tended to be higher with fumaric diets than with BAC $(P=0.08)$.
\end{abstract}

\section{fumaric acid / digestibility / caecum / rabbit}

Résumé - Effet de l'addition d'acide fumarique dans le régime de lapins en croissance sur la digestibilité de la ration et le milieu caecal. L'addition d'acide fumarique à deux doses distinctes $(5$ et $10 \mathrm{~g}$ par kg, LFA et HFA) dans le régime de lapins en croissance a été comparée, en termes de digestibilité apparente des nutriments et de contenu caecal, à l'addition d'une dose sub-thérapeutique de bacitracine-zinc (25 ppm, BAC) et à un traitement témoin (CTL). La digestibilité de la matière sèche (DMD) et celle de la matière organique (OMD) n'ont pas été significativement différentes entre les régimes contenant l'acide fumarique et les régimes $\mathrm{BAC}$ et $\mathrm{CTL}$, seules des différences ont été observées entre les régimes LFA et HFA (DMD : $P=0,05$ et OMD : $P=0,07$ ). La digestibilité des parois (NDF) n'a pas été affectée par les traitements $(P<0,10)$ alors que la quantité d'azote microbien ingérée issue des caecotrophes a eu tendance à être plus élevée $(P=0,09)$ avec les régimes LFA et HFA et à augmenter avec la dose d'acide fumarique. Bien qu'aucune différence n'ait été mise en évidence entre les régimes pour le nombre total de bactéries dans le contenu caecal, la concentration des bactéries amylolytiques a été supérieure avec les régimes LFA et HFA comparativement au régime $\operatorname{BAC}(P=0,08)$.

acide fumarique / digestibilité / caecum / lapins

* Corresponding author: mfonde@ posta.unizar.es 


\section{INTRODUCTION}

Organic acids are routinely included in diets for monogastric animals in Europe in order to replace antibiotics as growth promoters. The main effects of dietary organic acids in weaned piglets have been extensively reviewed $[14,16]$, consisting primarily of improved diet digestibility and growth performance, although not always, and performance improvements can be lower than those obtained with antibiotics as growth promoters [7]. The action mechanisms of organic acids are mainly involved in balancing the microbial population in the small intestine and/or to stimulating the activity of digestive enzymes [13].

Acidifiers have also been assayed for intensive rabbit production diets, either as organic acids $[5,9,11,17,20]$ or their salts [12], with research being focused mainly on both health and productive performances. However, because the importance of hindgut fermentation in feed utilisation is greater in rabbits than in young growing pigs, the possible effect of organic acids on the caecal environment cannot be overlooked.

The objective of this experiment was to evaluate to what extent fumaric acid, included at two levels in diets for growing rabbits may affect the caecal environment and diet digestibility, compared with either a control diet or a subtherapeutic dose of zinc Bacitracin, included as a positive control despite its use as a growth promoter not being allowed in the European Community.

\section{MATERIALS AND METHODS}

Thirty-two male New Zealand rabbits of $1436 \pm 22.2 \mathrm{~g}$ weight and aged 50 days at the beginning of the experiment were randomly allocated to four experimental treatments, resulting in 8 animals per treatment. In order to ease the management, the rabbits started the experiment in 8 subsequent periods (blocks), each consisting of one animal for each treatment. The animals were housed in individual cages provided with a feeder and suckling drinker in an environmentally controlled barn $\left(18-24{ }^{\circ} \mathrm{C}\right.$; $12 \mathrm{~h}$ light per day). A basal diet (g per kg: barley, 440; alfalfa hay, 240; sugar beet pulp, 82; soybean meal, 150; straw, 60; and a vitaminmineral mixture, 28) was supplemented with 5 (diet LFA) or 10 (HFA) g fumaric acid per $\mathrm{kg}$ or $25 \mathrm{ppm}$ zinc Bacitracin (BAC), and these experimental diets were contrasted with a control (CTL) diet without any supplement. The experimental diets were pelleted and given ad libitum.

The experimental period lasted for 21 days, consisting of $14 \mathrm{~d}$ of diet adaptation and $7 \mathrm{~d}$ of digestibility trial. On the 15 th day of the experiment, the rabbits were placed in metabolic cages and after $2 \mathrm{~d}$ of adaptation feed refusals, faeces and urine were collected daily for $5 \mathrm{~d}$. Faecal samples were collected daily, pooled individually and stored at $-20{ }^{\circ} \mathrm{C}$ until chemical analysis. Excreted urine was collected under $1 \mathrm{~mol} \mathrm{H}_{2} \mathrm{SO}_{4}$ per $\mathrm{L}$, weighed and diluted to $1000 \mathrm{~mL}$ with distilled water. A $200 \mathrm{~mL}$ sample was stored $\left(-20{ }^{\circ} \mathrm{C}\right)$ for subsequent purine analysis. The last day of the experiment, the rabbits were weighed and 5 rabbits per treatment were slaughtered between 11:00 and 12:00 after cervical dislocation. The digestive tract was dissected and the caecum was excised and weighed. Caecal $\mathrm{pH}$ was determined and samples were taken for ammonia concentration and bacterial counts as specified in Belenguer et al. [4].

Feeds and faeces were dried at $60^{\circ} \mathrm{C}$ for $48 \mathrm{~h}$ to determine their dry matter content (DM). Then, the samples were ground to 1 $\mathrm{mm}$ particle size and analysed for their organic matter $(\mathrm{OM})$ by ashing at $550{ }^{\circ} \mathrm{C}$ and $\mathrm{N}$ by the Kjeldahl method. Neutral detergent fibre (NDF) of feeds and faeces and acid detergent fibre (ADF) and acid detergent lignin (ADL) of feeds were determined according to Van Soest et al. [19], after amylase pretreatment and discounting the residual ashes. Urinary creatinine and microbial purine derivatives (PD: allantoin, xanthine, hypoxanthine and uric acid) 
Table I. Dry matter (DM) intake, daily growth and total tract apparent digestibility of dry matter (DMD), organic matter (OMD) and neutral detergent fibre (NDFD), together with urinary excretion of total purine derivatives (PD; mmol per d) and estimation of microbial $\mathrm{N}$ intake (Nm; g per d) in growing rabbits given a control diet (CTL) or diets supplemented with 5 (LFA), 10 (HFA) g fumaric acid per kg or 25 ppm zinc Bacitracin (BAC).

\begin{tabular}{lccccc}
\hline & CTL & LFA & HFA & BAC & s.e.m. \\
\hline Intake (g DM per d) & 119 & 132 & 130 & 125 & 7.5 \\
Growth (g per d) & 31.7 & 30.0 & 29.9 & 32.5 & 2.76 \\
DMD & $0.690 \mathrm{ab}$ & $0.676 \mathrm{~b}$ & $0.703 \mathrm{a}$ & $0.691 \mathrm{ab}$ & 0.0067 \\
OMD & 0.700 & 0.683 & 0.707 & 0.698 & 0.0062 \\
NDFD & 0.244 & 0.221 & 0.242 & 0.278 & 0.0156 \\
Total PD & 1.080 & 1.328 & 1.096 & 1.460 & 0.1403 \\
Nm intake & 1.530 & 1.962 & 2.521 & 1.534 & 0.2942 \\
\hline
\end{tabular}

s.e.m.: standard error of means.

For each row, different letters show significant differences $(P<0.05)$.

concentrations were analysed by reversephase HPLC as in Balcells et al. [3]. Microbial $\mathrm{N}$ intake $(\mathrm{Nm})$ was estimated from total PD excretion correcting for urinary losses using the creatinine excretion as a urinary marker and assuming a microbial purine bases: $\mathrm{N}$ ratio of 1.42 [2].

Ammonia concentration in caecal samples was determined colorimetrically following Chaney and Marbach [6]. Total, cellulolytic and amylolytic bacterial concentrations were determined by the most probable number procedure. Total and cellulolytic bacteria were cultivated simultaneously in the same medium as in Dehority et al. [8], and tubes for amylolytic counts included purified maize starch as the only substrate. Triplicate liquid media tubes were inoculated with serial dilution $\left(10^{-5}\right.$ to $10^{-10}$ for total and cellulolytic bacteria and $10^{-6}$ to $10^{-10}$ for amylolytic bacteria) and incubated for 14 and 7 days, respectively. Growth was estimated by final $\mathrm{pH}$, considering tubes with more than $0.2 \mathrm{pH}$ units lower than the maximum dilution as positive.

Treatments were compared statistically by ANOVA using the Statistix 8 statistical package [1]. The results were analysed as a factorial design, with the effect of period as a block. In cases of significant differences, treatment means were compared by the least significant difference procedure at $P<0.05$.

\section{RESULTS}

The average weight of the rabbits at the beginning of the experiment was not different among groups (1461, 1416, 1438 and $1439 \mathrm{~g}$ for CTL, LFA, HFA and BAC; s.e.m. 34.5). The coefficients of total tract apparent digestibility of dry matter (DMD), organic matter (OMD) and neutral detergent fibre (NDFD) are shown in Table I. Although the productive performance was not the objective of the study, daily intake and growth are also included as references in Table I. Supplementation with fumaric acid did not improve digestibility compared with the control or Bacitracin diets, but when LFA and HFA were compared, DMD $(P=0.05)$ increased when the dose of fumaric acid was doubled. The same trend $(P=0.07)$ was also observed for OMD. These differences were not significant in NDFD.

Urinary excretion of total purine derivatives (Tab. I) did not show significant differences among treatments. However, when total PD were corrected for a constant creatinine excretion to estimate microbial $\mathrm{N}$ 
Table II. Weight ( $\mathrm{g}$ ) of caecum and caecal content and $\mathrm{pH}$, ammonia concentration (mg per $\mathrm{L}$ ) and total $\left(\times 10^{8}\right.$ per $\left.\mathrm{g}\right)$, amylolytic $\left(\times 10^{8}\right.$ per $\left.\mathrm{g}\right)$ and cellulolytic $\left(\times 10^{5}\right.$ per $\left.\mathrm{g}\right)$ bacterial concentration in caecal contents of growing rabbits given a control diet (CTL) or diets supplemented with 5 (LFA) or 10 (HFA) g fumaric acid per kg or 25 ppm zinc Bacitracin (BAC).

\begin{tabular}{lccccc}
\hline & CTL & LFA & HFA & BAC & s.e.m. \\
\hline Caecum weight & 133.6 & 135.4 & 133.0 & 132.7 & 9.14 \\
Content weight & 95.8 & 100.5 & 91.2 & 93.5 & 7.79 \\
$\mathrm{pH}$ & 5.87 & 5.85 & 5.79 & 5.87 & 0.124 \\
Ammonia & 23.6 & 41.4 & 38.2 & 28.7 & 9.74 \\
Total bacteria & 21.1 & 19.5 & 31.8 & 22.8 & 6.91 \\
Amylolytic & 5.8 & 23.6 & 9.4 & 1.5 & 5.86 \\
Cellulolytic & 16.0 & 5.5 & 38.7 & 3.1 & 16.18 \\
\hline
\end{tabular}

s.e.m.: standard error of means.

intake, the values for this parameter tended $(P=0.09)$ to be higher with HFA than with either CTL or BAC diets.

Caecal characteristics, including weight of the organ and its content, $\mathrm{pH}$ and ammonia and bacterial concentration in caecal contents are shown in Table II. No significant differences were detected for either the full caecum weight or the caecum content weight, nor in caecum $\mathrm{pH}$ and ammonia caecal concentration, even though ammonia concentration with CTL was numerically lower than both fumaric diets $(P>0.10)$. Differences in total bacterial concentration were not significant, but caecal concentration of amylolytic bacteria tended $(P=0.08)$ to increase when fumaric acid was included in the diet compared with BAC, to a higher extent with LFA than with HFA. In contrast, cellulolytic bacterial concentration was not significantly lower in LFA than in HFA. In any case, it is necessary to consider the high magnitude of the error term, inherent to bacterial counting parameters.

\section{DISCUSSION}

Most available information about the use of acidifiers in animal feeding is focused on pigs $[10,15,16]$. As reviewed by Partanen and Mroz [14], improvements in diet digestibility are variable and often not significant, rarely exceeding 0.003 . The effects in digestibility and productive performances of the inclusion of organic acids in rabbit nutrition are not clear. Improvements in daily gain have been reported by ZiLin et al. [20] including $1.25 \mathrm{~g}$ fumaric acid per $\mathrm{kg}$ and by Castrovilli [4] and Hullar et al. [12] with different acidifiers included at 1.5 or $3.0 \mathrm{~g}$ per $\mathrm{kg}$, but no effects were recorded by others [11, 17]. Hullar et al. [12] also reported an increase in diet digestibility by adding sodium butyrate, and El-Kerdawy [9] observed that $0.5 \%$ fumaric acid did not affect total tract apparent digestibility of dry matter or organic matter of growing rabbits, although digestibility of crude protein and crude fibre significantly increased.

The magnitude of the response to antimicrobial agents, either acidifiers or antibiotics, is strongly influenced by the cleanliness of the environment, and therefore a minor effect can be expected when tested in a clean and less stressing environment [7]. No positive effect of the inclusion of the acidifier in the diet on DMD or OMD compared with CTL or by 25 ppm zinc Bacitracin (BAC) was statistically detected. However, a significant response to the dose of fumaric acid was observed. Some authors have also observed a lack of response of 
similar levels of fumaric acid on the digestibility of dietary energy or crude protein in weaned pigs $[10,15]$.

The importance of the effects of acidifiers in the small intestine for nutrient utilisation, either as antimicrobials or through an enhancement of enzymatic or absorption capabilities, has been pointed out $[12,14$, 16]. In rabbits, the microbial population in the caecum contributes to an important extent to total tract digestion and nutrient utilisation. Therefore, despite the measurement of diet digestibility, a quantitative and qualitative evaluation of the caecal environment would give an idea of any effect that acidifiers may have in rabbit nutrition.

No dietary effect was observed on caecal $\mathrm{pH}$. This can be attributed either to a major absorption of the acidifier before reaching the organ or to a sufficient buffering capacity of caecal content, that in all cases resulted around 5.8-5.9. Urinary excretion of PD is an index of microbial protein intake as caecotrophes [2] and may indirectly give a quantitative idea of the microbial caecal population. When microbial $\mathrm{N}$ intake is estimated, a possible bias in the urinary recovery can be corrected by urinary excretion of creatinine, assuming that its excretion on a metabolic weight basis is constant [18]. Although neither acidifier nor zinc Bacitracin addition affected PD excretion, fumaric diets promoted $(P=0.09)$ higher intake of microbial $\mathrm{N}$ as caecotrophes, indicating that caecal microbial yield was increased by including fumaric acid in the diet. The results of urinary excretion of total purine derivatives do not agree with the lack of effect of the experimental treatments on total bacterial concentration. However, amylolytic bacteria tended $(P=0.08)$ to increase with the level of inclusion of fumaric acid in the diet, also compared with Bacitracin treatment. Differences in specific bacterial populations without changes in total anaerobic bacterial counts might suggest a dietary shift of the caecal population. Total and cellulolytic bacterial num- bers are close to those previously observed with a similar dietary NDF proportion [4].

In conclusion, the inclusion of 5 and $10 \mathrm{~g}$ per $\mathrm{kg}$ of fumaric acid in the diet does not apparently affect the caecal environment of growing rabbits, except for a higher concentration of amylolytic bacteria. In contrast, the results from PD excretion would also support a higher microbial caecal synthesis. It can be assumed that the effect of the acidifier in a hindgut fermenter would possibly affect the small intestine to a larger extent than the large intestine. In any case, no major positive response over the control was observed on diet digestibility. The use of zinc Bacitracin at a subtherapeutic dose did not show any benefit over the control in the controlled environment of our experimental conditions. The statistical comparison between doses of fumaric acid showed a positive response on a higher diet digestibility and microbial $\mathrm{N}$ intake when included at 10 instead of $5 \mathrm{~g}$ per $\mathrm{kg}$.

\section{ACKNOWLEDGEMENTS}

This work was financed by Cargill, S.L. through the Project PTR 95/0405-OP. Thanks are given to the Servicio de Experimentación Animal (Universidad de Zaragoza).

\section{REFERENCES}

[1] Analytical Software, Statistix 8, Analytical Software, Tallahasee FL, USA, 2003.

[2] Balcells J., Ganuza J.M., Pérez J.F., MartínOrúe S.M., González Ronquillo M., Urinary excretion of purine derivatives as an index of microbial nitrogen intake in growing rabbits, Brit. J. Nutr. 79 (1998) 373-380.

[3] Balcells J., Guada J.A., Peiró J.M., Parker D.S., Simultaneous determination of allantoin and oxypurines in biological fluids by highperformance liquid chromatography, J. Chromatogr. 575 (1992) 153-157.

[4] Belenguer A., Balcells J., Fondevila M., Torre C., Caecotrophes intake in growing rabbits estimated either from urinary excretion of purine derivatives or from direct measurement using animals provided with a neck collar: effect of type and level of dietary carbohydrate, Anim. Sci. 74 (2002) 135-144. 
[5] Castrovilli C., Acidification of feeds for fattening rabbits, Riv. Conigliocult. 38 (1991) 31-34.

[6] Chaney A.L., Marbach E.P., Modified reagents for determination of urea and ammonia, Clin. Chem. 8 (1962) 130-132.

[7] Cromwell G.L., Antimicrobial and promicrobial agents, in: Lewis A.J., Southern L.L. (Eds.), Swine nutrition, CRC Press, Boca Raton, USA, 2001, pp. 401-426.

[8] Dehority B.A., Tirabasso P.A., Grifo A.P., Most-probable number procedures for enumerating ruminal bacteria, including the simultaneous estimation of total and cellulolytic numbers in one medium, Appl. Environ. Microbiol. 55 (1989) 2789-2792.

[9] El-Kerdawy D.M.A., Acidified feeds for growing rabbits, Egypt J. Rabbit Sci. 6 (1996) 143-156.

[10] Giesting D.W., Easter R.A., Response of starter pigs to supplementation of corn soybean meal diets with organic acids, J. Anim. Sci. 60 (1985) 1288-1294.

[11] Hollister A.G., Cheeke P.R., Robinson K.L., Patton N.M., Effects of dietary probiotics and acidifiers on performance of weaning rabbits, J. Appl. Rabbit Res. 13 (1990) 6-9.

[12] Hullar I., Fekete S., Szigeti G., Bokori J., Sodium butyrate as a natural growth promoter for rabbits, 6th World Rabbit Congress, Toulouse, France, Vol. 2, 1996, pp. 175-179.

[13] Knarreborg A., Miquel N., Granli T., Jensen B.B., Establishment and application of an in vitro methodology to study the effects of organic acids on coliform and lactic acid bacteria in the proximal part of the gastrointestinal tract of piglets, Anim. Feed Sci. Technol. 99 (2002) 131-140

[14] Partanen K.H., MrozZ., Organic acids for performance enhancement in pig diets, Nutr. Res. Rev. 12 (1999) 117-145.

[15] Radecki S.V., Juhl M.R., Miller E.R., Fumaric and citric acids as feed additives in starter pig diets: effect on performance and nutrient balance, J. Anim. Sci. 66 (1988) 2598-2605.

[16] Ravindran V., Kornegay E.T., Acidification of weaner pig diets: a review, J. Sci. Food Agric. 62 (1993) 313-322.

[17] Scapinello C., Faria H.G., Furlan A.C., Michelan A.C., Efeito da utilizaçao de oligossacarídeo manose e acidificantes sobre o desempenho de coelhos em crescimento, Rev. Bras. Zootec. 30 (2001) 1272-1277.

[18] Van Niekerk B.D.H., Reid J.T., Bensadoun A., Paladines O.L., Urinary creatinine as an index of body composition, J. Nutr. 63 (1963) 463-473.

[19] Van Soest P.J., Robertson J.B., Lewis B.A., Methods for dietary fiber, neutral detergent fiber and nonstarch polysaccharides in relation to animal nutrition, J. Dairy Sci. 74 (1991) 3583-3597.

[20] Zi Lin G., Ren Lu H., Wen She R., Guo Xian Z., Yu Ting H., The effects of BFA on weight gain and coccidiosis in meat rabbits, 6th World Rabbit Congress, Toulouse, France, Vol. 3, 1996, pp. 73-76. 